\title{
Studies in the Diabetic Mutant Mouse: I. Light Microscopy and Radioautography of Pancreatic Islets*
}

\author{
A.A. LrKE**, and W.L. CHICK*** \\ Elliott P. Joslin Research Laboratory, Departments of Pathology and Medicine, Harvard Medical School, The Peter \\ Bent Brigham Hospital and The Joslin Diabotes Foundation, Ine., Boston, Massachusetts, USA
}

Summary. Light microscopic and radioautographic studies were performed in normal (C $57 \mathrm{BL} / \mathrm{KsJ})$ and in diabetic mutant (C $57 \mathrm{BL} / \mathrm{Ks}-d b / d b$ ) mice following thy. midine ${ }^{3} \mathrm{H}$ administration. The pancreatic islets of normal mice were small, beta cells well granulated and a rare islet cell incorporated thymidine ${ }^{3} \mathbf{H}$. In prehyperglycemic mutants (blood glucose $<120 \mathrm{mg} / 100 \mathrm{ml}$ ) beta cells were also well granulated but incorporated thymidine ${ }^{3} \mathrm{H}$ with greater frequency than observed in normal mice. With the onset of early hyperglycemia (blood glucose 130-200 $\mathrm{mgm} / 100 \mathrm{ml}$ ) and hyperinsulinemia, the islets were normal in size, however beta cells were partially degranulated and numerous islet colls were labeled with thymidine ${ }^{3} \mathrm{H}$. With established hyperglycemia (blood glucose $<200$ $\mathrm{mg} / 100 \mathrm{ml}$ ) serum IRI was greatly increased, beta cell degranulation pronounced, labeled islet cells numerous, and islet enlargement noteworthy. The terminal phase of the syndrome was characterized by a decrease in the number of beta cells and a unique proliferation of small ductal structures. Labeled ductal cells were numerous, labeled endocrine islet cells infrequent and the animals succumbed in a state of relative insulin insufficiency.

Etudes de la mutation dbdb chez la souris. I. Mieroscopie optique et autoradiographie des îlots pancréatiques

Résumé. Des études en microscopie optique et autoradiographiques ont été effectuées chez des souris normales (C $57 \mathrm{BL} / \mathrm{KsJ}$ ) et chez leurs mutants diabétiques (C $57 \mathrm{BL} / \mathrm{Ks}-d b / d b)$ après l'administration de la ${ }^{3} \mathrm{H}$-thymidine. Les îlots pancréatiques sont petits chez la souris normale, les cellules $\beta$ sont bien granulées et de rares cellules endocrines incorporent la ${ }^{3} \mathrm{H}$-thymidine. Les cellules $\beta$ des mutants préhyperglycémiques (taux de glucose sanguin $<120 \mathrm{mg} \%$ ) sont aussi bien granulées mais incorporent mieux la ${ }^{3} \mathrm{H}$-thymidine que celles des souris normales. Avec l'apparition de l'hyperglycémie précoce (glucose sanguin 130-200 $\mathrm{mg} \%$ ) et de l'hyperinsulinémie, la dimension des îlots reste normale, mais on observe une dégranulation partielle des cellules $\beta$ et une incorporation de la ${ }^{3} \mathrm{H}$-thymidine dans un grand nombre de cellules pancréatiques. Chez les animaux présentant une hyperglycémie nette (glucose sanguin $<200 \mathrm{mg} \%$ ), l'insuline circulante est considérablement accrue, la dégranulation des cellules $\beta$ est prononcée, le nombre d'îlots marqués très grand et l'élargissement des îlots est très net. La phase terminale du syndrome est caractérisée par une diminution du nombre des cellules $\beta$ et une prolifération remarquable de petits canaux. Les cellules ductales marquées sont nombreuses, tandis que les cellules du pancréas endocrine marquées sont peu fréquentes et les animaux meurent dans un état d'insuffisance relative d'insuline.

Der Diabetes der abdb-Maus: I. Lichtmikroskopische und autoradiographische Untersuchungen der Langerhans' schen Inseln

Zusammenfassung. Pankreasgewebe von hereditär diabetischen $(d b / d b)$ und normalen Kontrollmäusen wurde nach in vivo Injektion von Thymidin ${ }^{3} \mathrm{H}$ lichtmikroskopisch und autoradiographisch untersucht. Die Langerhans'schen Inseln normaler Mäuse waren klein, die BZellen granuliert und nur selten konnte Inkorporation von Radioaktivität in Inselzellen festgestellt werden. Bei jungen, noch nicht hyperglykämischen $d b / d b$ Mäusen (Blutzucker unter $120 \mathrm{mg} / 100 \mathrm{ml}$ ) waren die B-Zellen ebenfalls granuliert, doch waren häufiger Thymidininkorporierende Inselzellen nachzuweisen als bei den Kontrolltieren. In der durch Hyperinsulinaemie charakterisierten Anfangsphase des hyperglykämischen Syndroms (Blutzucker $130-200 \mathrm{mg} / 100 \mathrm{ml}$ ) waren die Inseln normal groß, die B-Zellen waren teilwoise degranuliert und zahlreiche Inselzellen enthielten Thymidin- ${ }^{3}$ H-Radioaktivität. Nach Erreichen von Blutzuckerkonzentrationen über $200 \mathrm{mg} / 100 \mathrm{ml}$ und bei noch immer erhöhter Seruminsulinkonzentration waren die Inseln deutlich vergrößert, die B-Zellen degranuliert und zahlreiche Inselzellen mit Radioaktivitätt markiert. Während der terminalen Phase des Syndroms nahm die Zahl der BZellen deutlich $a b$ und es trat eine intrainsuläre Proliferation kanikulärer Strukturen auf. Die Zellen dieser Gebilde inkorporierten viel Thymidin, dagegen wurden nur selten markierte endokrine Inselzellen beobachtet. Die Tiere starben in einem Zustand relativer Insulininsuffizienz.

Key-words: Spontaneous diabetes, genotype: C $57 \mathrm{BL} /$ $\mathrm{Ks}-d b / d b$, hereditary diabetes in mice, mutation: diabetes, pancreatic islets, islets of Langerhans, beta cell replication, mitotic activity, radioautography.
In 1965 a diabetic mutant was discovered among the inbred mice $\mathrm{C} 57 \mathrm{BL} / \mathrm{K}_{\mathrm{SJ}} \mathrm{J}$. In a series of publications from The Jackson Laboratory $[8,2,3]$, a number of unique characteristics were documented. The diabetic

* Supported in part by USPHS Grants AM-12538, AM- 09584, and AM- 05077.

** USPHS Research Career Development Awardee, Grant K4-AM-7394.

*** USPHS Special Postdoctoral Fellowship Awardee, Grant F3-AM-36335 mutation is an expression of a single autosomal recessive gene $(d b)$ with complete penetrance in homozygous mice $(d b / d b)$. The syndrome is characterized by early (3 to 4 weeks of age) obesity and increased levels of plasma immunoreactive insulin, followed (at 5 to 6 weeks of age) by hyperglycemia, glycosuria, correspondingly higher levels of plasma insulin and a rapid progression of fat deposition. During the early stage of the syndrome, there is increased systemic glucose oxidation and hepatic gluconeogenesis. Subsequently, plasma 
insulin fell, hyperglycemia was even more pronounced, and weight loss occurred prior to death at 5 to 7 months of age. The late phenomena were associated with marked insulin resistance and decreased glucose utilization, but with a continued high rate af hepatic gluconeogenesis. The pancreatic islets, reportedly the only site of morphologic alterations, underwent a progression of changes characterized by initial beta cell degranulation and subsequent proliferation of pancreatic ducts around and within the islets with resulting islet cell neogenesis.

We elected to conduct further morphologic studies on these animals in order to examine the kinetics of islet cell proliferation during the several stages of the syndrome by means of radioautography after thymidine- ${ }^{3} \mathrm{H}$ administration. We also undertook to expand the scope of the investigation beyond the initial light microscopy to include an ultrastructural examination of the pancreatic islets during the early, well-established and late stages of the syndrome.

In this report we shall present the results of conventional light microscopic and radioautographic studies of the islets of normal (C $57 \mathrm{BL} / \mathrm{KsJ}_{\mathrm{sJ}}$ ) mice, and the changes observed in the islets of diabetic mutants (C $57 \mathrm{BL} / \mathrm{Ks}-d b / d b)$. A companion paper [10] will detail the results of the electron microscopic examination conducted on the same animals. Since physiologic studies were also performed [1], structural-functional correlations will be presented whenever possible.

\section{Materials and Methods}

Seventy-eight diabetic mutant (C $57 \mathrm{BL} / \mathrm{Ks}-d b / d b)$ and 43 normal (C $57 \mathrm{BL} \mathrm{KsJ}$ ) mice of both sexes were studied. The animals were obtained from two sources: the Production Department Colony and the Research Colony of The Jackson Laboratory, Bar Harbor, Maine. Fifty-seven of the mutants with adequate blood glucose and serum insulin data were divided into four groups according to the stage of the syndrome:

Prehyperglycemic: 11 mice, age $4-6$ weeks with blood glucose $(\mathrm{BG})<120 \mathrm{mg} / 100 \mathrm{ml}$.

Early hyperglycemic: 10 mice, age 5-7 weeks, already somewhat obese with $\mathrm{BG} 120-200 \mathrm{mg} / 100 \mathrm{ml}$.

Established hyperglycemic: 8 mice, age $8-20$ weeks, markedly obese, with $\mathrm{BG} 200-400 \mathrm{mg} / 100 \mathrm{ml}$.

Terminal: 28 mice, age $11-24$ weeks, with weight loss, reduced serum insulin and $B G>400 \mathrm{mg} / 100 \mathrm{ml}$. Two of these mice were 8 weeks of age. Age-matched normal mice of both sexes were studied with each of the four groups. While at The Jackson Laboratory the animals were maintained on Old Guilford mouse pellets ${ }^{1}$ containing $6 \%$ fat. After transfer to the Joslin Research Laboratory they were fed Old Guilford mouse pellets with a $7.5 \%$ fat content. The increase in fat content is the result of the addition of a quantity of wheat

1 Emory Morse Company, Guilford, Connecticut. germ to the pellet ingredients. All animals were allowed free access to food and water during the entire study. Body weights were determined at weekly intervals. Blood glucose (BG) was measured at weekly or bimonthly intervals using $0.05 \mathrm{ml}$ of tail blood by the ferricyanide method of Hoffman [7] as modified for the Technicon autoanalyzer. Serum immunoreactive insulin (IRI) was measured $[1,15,18]$ usually on serum samples obtained at the time of killing. Thymidine- ${ }^{3} H^{2} \quad(1-10$ microcuries per g body weight) was given intraperitoneally to 38 mice two hours prior to sacrifice. Many of these mice were subjected to rapid decapitation and exsanguination with blood collected for blood glucose and serum IRI determinations. Approximately two-thirds of each pancreas was subjected to collagenase digestion for the preparation of isolated islets of Langerhans [9] which were utilized for the determinations of thymidine- ${ }^{3} \mathrm{H}$ incorporation into islet DNA [1]. The remainder of the pancreas and an attached portion of duodenum were fixed in Bouin's solution for light microscopic examination and radioautography. In 14 of the mice, pancreatic tissue was also fixed for electron microscopy. In most of the mice not receiving thymidine ${ }^{3} \mathrm{H}$, intraperitoneal Nembutal, 0.05 $\mathrm{mg} / \mathrm{gm}$ body weight, induced anesthesia after which portions of the pancreas were fixed for electron microscopy [10], and the remainder with an attached segment of duodenum fixed in Bouin's solution. A thorough autopsy was performed on each mouse killed. For conventional light microscopy, paraffin-embedded sections were stained with $\mathrm{H} \& \mathrm{E}, \mathrm{PAS}$, and a modified aldehyde-fuchsin stain [19]. For radioautography, paraffin sections were mounted on gelatin-coated slides. After deparaffinization and exposure to $0.5 \%$ periodic acid, the slides were washed, dehydrated, air-dried and coated with Kodak Nuclear Track Emulsion NTB-2. After exposure for one to four weeks in Drierite-containing light-tight boxes, stored at approximately $4^{\circ} \mathrm{C}$, the emulsion was developed in freshly prepared Kodak Dektol developer for $1 \frac{1 / 2}{2}$ to $2 \mathrm{~min}$ at $18^{\circ} \mathrm{C}$ and fixed for $3 \mathrm{~min}$ in Kodak Acid Fixer. After thorough washing, the slides were placed in Schiff's reagent for the completion of the PAS stain.

Results
Physiologic studies
Only a very brief resume of these studies will be
presented here. The reader is referred to the companion
paper [1] for the full report of the physiologic studies.
When one compares the body weights of the normal
mice and the diabetic mutants, it is clear that although
the normal mice rarely exceed $30 \mathrm{~g}$, the weight of most
diabetic mutants are already greater than $30 \mathrm{~g}$ at 6 to 7
weeks of age, and usually reach 50 to $60 \mathrm{~g}$ prior to the
onset of weight loss that characterizes the terminal
tage of the syndrome.

2 Thymidine-methyl ${ }^{3} \mathrm{H}$, sp. activity 10 curies per mmole, Schwarz BioResearch Inc. 
In Fig. 1 and 2 the mean $B G$ and serum IRI levels of the mutant mice between 4 and 27 weeks of age with those obtained for normal mice.

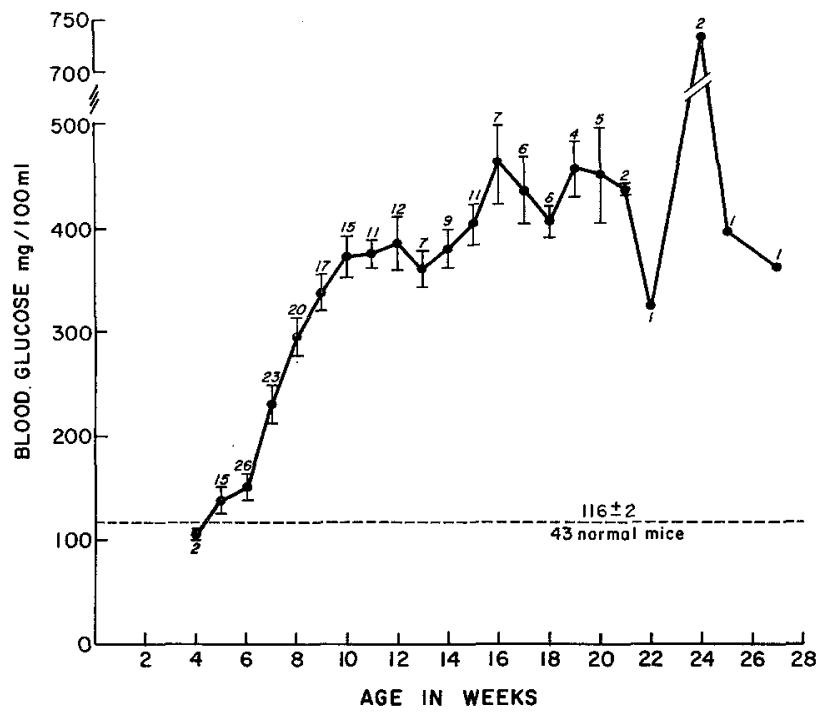

Fig. 1. Mean levels of blood glucose concentration of diabetic mutant mice as a function of age. The mean blood glucose concentration of 43 normal mice is included for comparison

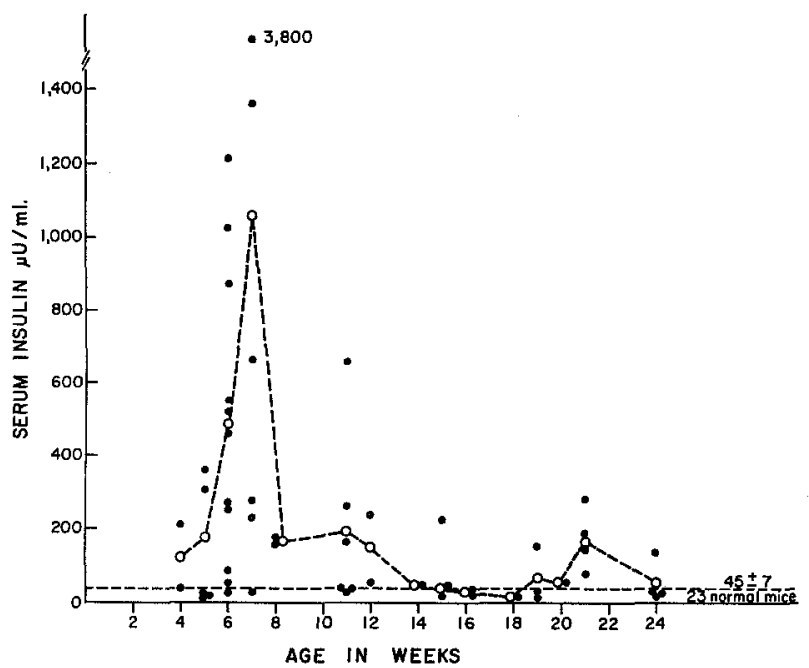

Fig. 2. Mean levels of serum immunoreactive insulin concentrations of diabetic mutant mice as a function of age. The mean serum insulin level of 23 normal mice is included for comparison

Although individual values above $130 \mathrm{mg} / 100 \mathrm{~m}$ are recorded, the mean $\mathrm{BG}$ of the diabetic mutants is not elevated at 4 weeks of age. With few exceptions however, BG levels are consistently elevated above $130 \mathrm{mg} / 100 \mathrm{ml}$ at 6 to 7 weeks. There is a progressive increase in hyperglycemia until 15 weeks of age when there is relative stabilization in the 400 to $500 \mathrm{mg} /$ $100 \mathrm{ml}$ range for the duration of the syndrome.
Mean serum IRI levels, on the other hand, are elevated at 4 to 5 weeks of age. Although greater indiviual variations are recorded than is true for blood glucose, so me degree of hyperinsulinemia is almost always present prior to the terminal phase of the syndrome, at which time serum IRI returns to normal or below normal levels.
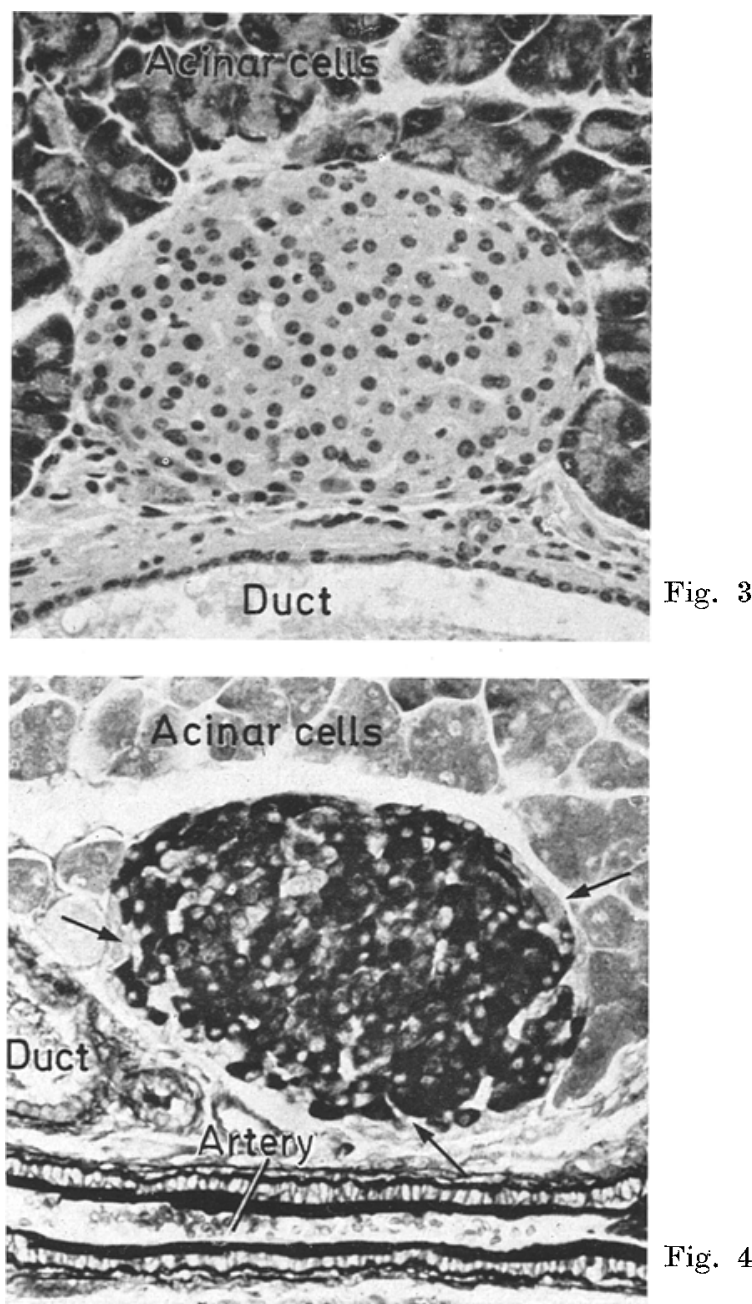

Figs. 3 and 4. Pancreatic islets of normal C57BL/KsJ mice

Fig. 3. Hematoxylin and eosin: acinar and islet components are elearly separated from one another. The islet is adjacent to an exocrine duct, $\times 256$. Fig. 4. Aldehyde fuchsin stain: the deeply staining well granulated beta cells (black in photograph) are characteristic of normal mice. Peripheral alpha cells are indicated by arrows. $\times 256$

Two mutants which portray the most severe degree of early carbohydrate intolerance are mice No. A 30 B and $A 30 \mathrm{~L}$. Blood glucose values of 328 and $468 \mathrm{mg} /$ $100 \mathrm{ml}$ were recorded at 6 weeks, and values in excess of $500 \mathrm{mg} / 100 \mathrm{ml}$ at 7 weeks of age. One week later, at the time of killing, these levels of glycemia were maintained and serum IRI values in the normal range (40 to $50 \mu \mathrm{U} / \mathrm{ml}$ ) were documented. 
Although the age range for the onset of hyperglycemia and hyperinsulinemia is limited (BG 4 to 6 weeks, IRI 4 to 5 weeks), the time of entry into the terminal stage of the syndrome is less predictable, with the age of onset of weight loss varying from 10 to 24 weeks. On the basis of depressed serum IRI however, most mice are in the terminal stage after 14 to 16 weeks of age.

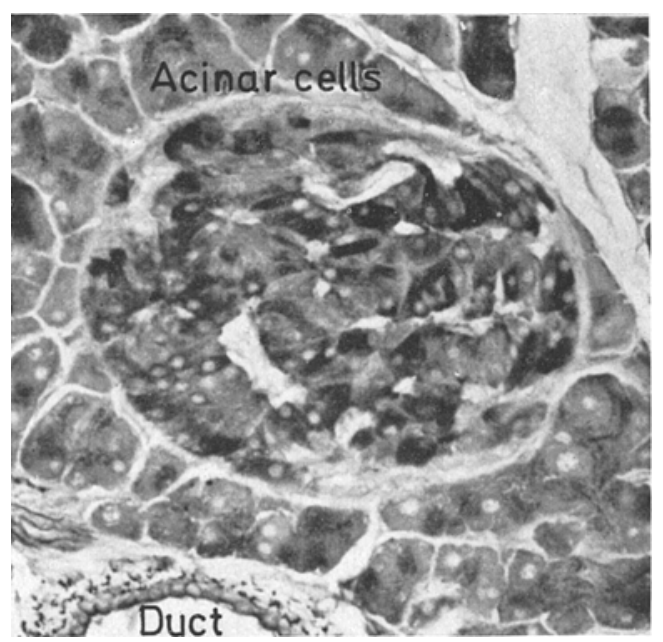

Fig. 5. Pancreatic islet of a diabetic mutant mouse (C 57 $\mathrm{BL} / \mathrm{Ks}-d b / d b)$ with early hyperglycemia and increased levels of serum insulin. The beta cells are partially degranulated. Aldehyde fuchsin stain. $\times 256$ of individual islets of normal mice, most are small rounded or oval in shape when viewed in two dimensions, and all are sharply delineated from the surrounding acinar tissue. Although frequently in close contact with small pancreatic ducts, the two structures are always clearly demarcated from one another usually by a small quantity of fibrocollagen (Fig. 3). Aldehydefuchsin-stained preparations invariably reveal a central grouping of well-granulated beta cells surrounded by a mantle of alpha cells (Fig. 4). Although there is some variation in the number of alpha cells visible in each islet, they are almost without exception grouped at the periphery of the islet separating the innermost beta cells from the adjacent exocrine pancreas.

Diabetic Mutants. Prior to the onset of advanced hyperglycemia, the appearance of the islets of Langerhans is somewhat variable. In prehyperglycemic animals $(B G<120 \mathrm{mg} / 100 \mathrm{ml}$ ) the islets can not be distinguished from those of the normal mice, using criteria of size, shape and the presence of uniformly well-granulated (aldehyde fuchsin positive) beta cells. The serum IRI levels in these mice however are usually somewhat elevated.

The first detectable histologic manifestation of the diabetic syndrome is the presence of partial beta cell degranulation in aldehyde fuchsin stained preparations (Fig. 5). Although observed in the early hyperglycemic mice, (BG 130 to $200 \mathrm{mg} / 100 \mathrm{ml}$ ) beta cell degranulation is almost always associated with markedly in-

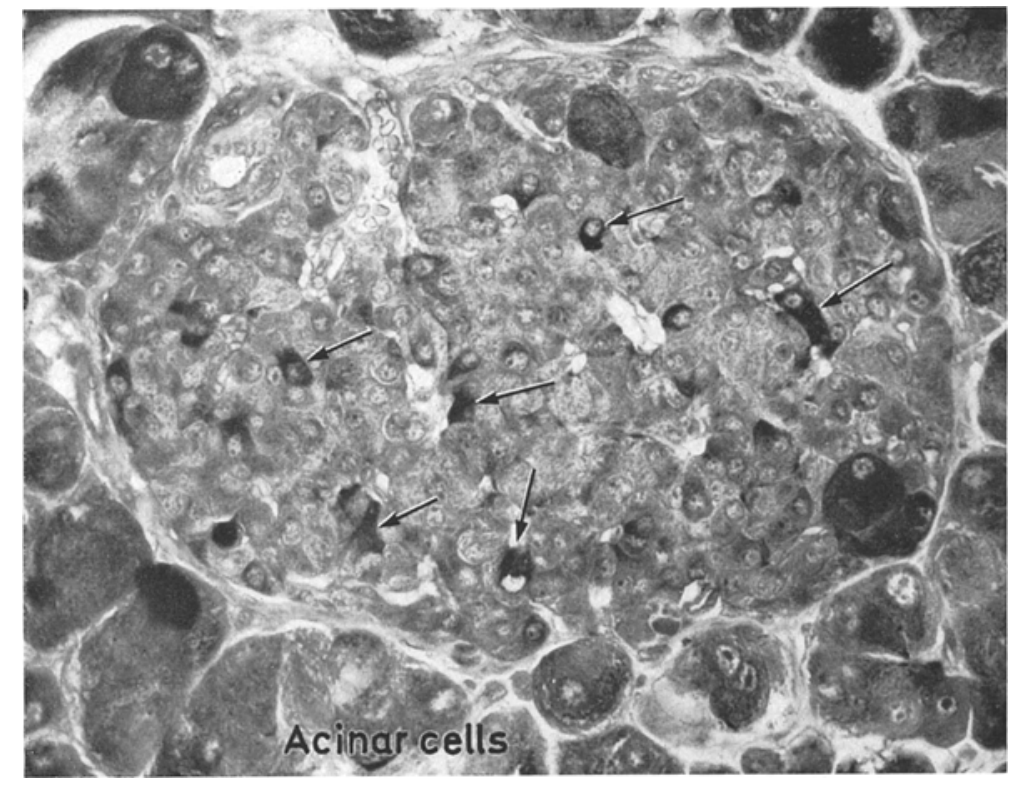

Fig. 6. Pancreas of a diabetic mouse with established hyperglycemia and hyperinsulinemia. The islet is increased in size. A small number of the beta cells contain aldehyde fuchsin positive granules (arrows). Most however are devoid of stored insulin. Aldehyde fuchsin stain $\times \mathbf{4 0 0}$

\section{Conventional histologic studies}

Normal Mice. The pancreatic islets of the normal C $57 \mathrm{BL} / \mathrm{Ks} \mathrm{J}$ mice can not be distinguished from those of other normal mice studied in this laboratory $[13,12$. Although there is a striking variation in the diameter creased levels of serum IRI and frequently with a mild increase in overall islet size. With further increases of glycemic levels (established hyperglycemia) beta cell degranulation is more pronounced and often complete (Fig. 6), islet size is moderately larger and serum IRI elevations sustained. 
In the later evolution (terminal phase) of the diabetic syndrome, serum IRI levels fall and eventually return to normal or below normal levels. Although there is variability from islet to islet and among animals, there are morphologic alterations within most islets which can be correlated with, and in fact predict the reduction in serum IRI. The overall configuration of the islets is altered. The typically oval or circular cuboidal epithelium and resemble the small ducts of the exocrine pancreas except for the fact that they contain a greater quantity of luminal secretory material which is eosinophilic, bright pink with the PAS stain and deep purple with the aldehyde fuchsin stain (Fig. 7). In association with the intra-islet ductal structures there is a clearcut decrease in the number of beta cells. The alpha cells although not increased in number
Figs. 7-8. Pancreatic islets of diabetic mice in terminal phase of syndrome: Fig. 7. Several beta cells (B) retain their storage granules. Dilated ducts are filled with a secretory product. Several aldehyde fuchsin positive cells (arrows) appear to be close to or on the luminal surface of the duct. Aldehyde fuchsin stain. $\times$ 400. Fig. 8 . The islet configuration is retained. Beta cell degranulation is virtually complete. Alpha cells (arrows) are randomly scattered throughout the islet interior. Aldehyde fuchsin stain $\times 400$
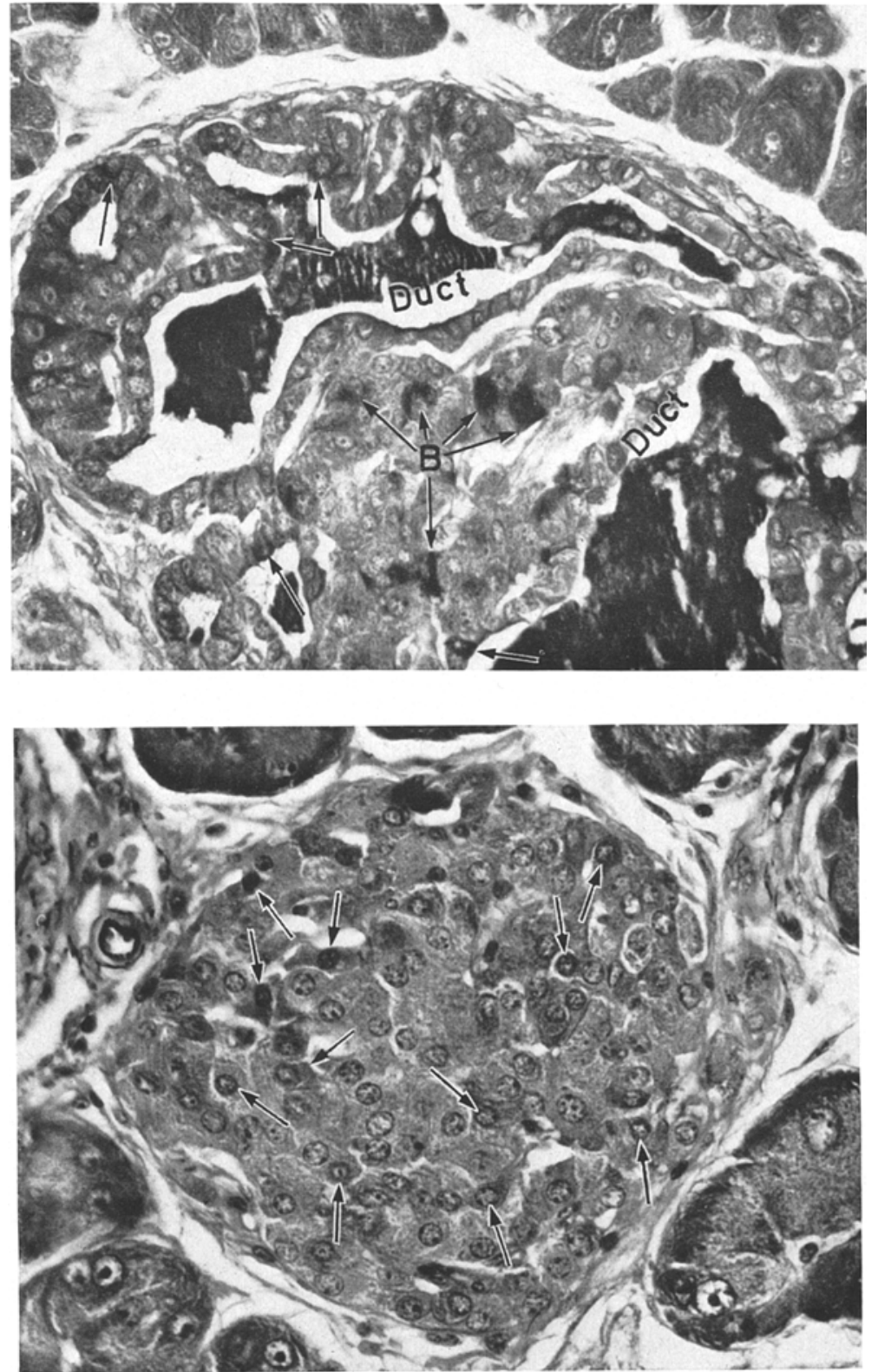

islet, sharply delineated from the surrounding exocrine pancreas, is frequently replaced by islets having an irregular contour. Numerous small and sometimes dilated ductal structures surround and often permeate the interior of the islet. The ducts are lined with a low are now located within the interior of the islet as well as at the periphery. Theintra-islet ducts are in in timate juxtaposition with the remaining clusters of islet cells and intra-islet collections of chronic inflammatory cells as well as foci of peri-insular and intra-insular fibrosis 
(Fig. 11). The latter is in a small way responsible for the irregular islet configuration. The remaining beta cells are almost always completely degranulated and a number of the ductal lining cells stain positively with the PAS and aldehyde fuchsin stain.

The variable appearance of an individual islet is governed by the relative importance of each of the described morphologic alterations. Most islets present a mixture of all components, but at the extreme ends of the spectrum there are: 1 . islets of normal configuration with complete beta cell degranulation and a random intermingling of alpha and beta cells (Fig. 8); 2 . clusters of dilated ductal structures with no or very few recognizable islet cells (Fig. 9); 3. collections of acinar cells and ducts surrounded and/or permeated by fibrocollagen, and having an islet-like configuration (Figs. 10, 11).

The exocrine pancreas of mutant and normal mice can not be differentiated.

\section{Radioautographic Studies}

General Comments. In the descriptive account which follows, the term "labeled cell" and "labeling" are used to designate the presence of a cluster of discrete black grains situated in the photographic emulsion overlying correlated extremely well with the determination of thymidine- ${ }^{3} \mathrm{H}$ incorporation into islet DNA, expressed as DPM per microgram islet DNA utilizing islets isolated from the same animals [1].

Normal Mice. There are very few labeled cells among the islets of normal mice at all ages examined. In most instances a random section of the entire pancreas contains a total of not more than 5 labeled. islet cells. Acinar cell labeling although more common is also quite infrequent. Intrapancreatic lymph nodes are heavily labeled.

Diabetic Mutants. There is a mild but definite increase in the number of labeled islet cells in most prehyperglycemic mice $(\mathrm{BG}<120 \mathrm{mg} / 100 \mathrm{ml}$ ). On the other hand, the islets of early hyperglycemic animals (BG 130 to $200 \mathrm{mg} / 100 \mathrm{ml}$ ), reveal a striking increase in the number of labeled cells (Fig. 12). There is no greater frequency of labeling within small (Fig. 13) or large islets and no apparent preferential localization of labeled cells at the islet periphery or interior [6].

The number of labeled islet cells is also increased in animals with established hyperglycemia although the magnitude is not as great as in the younger mice. The two groups are always separable and cell counts are not required to document the difference.

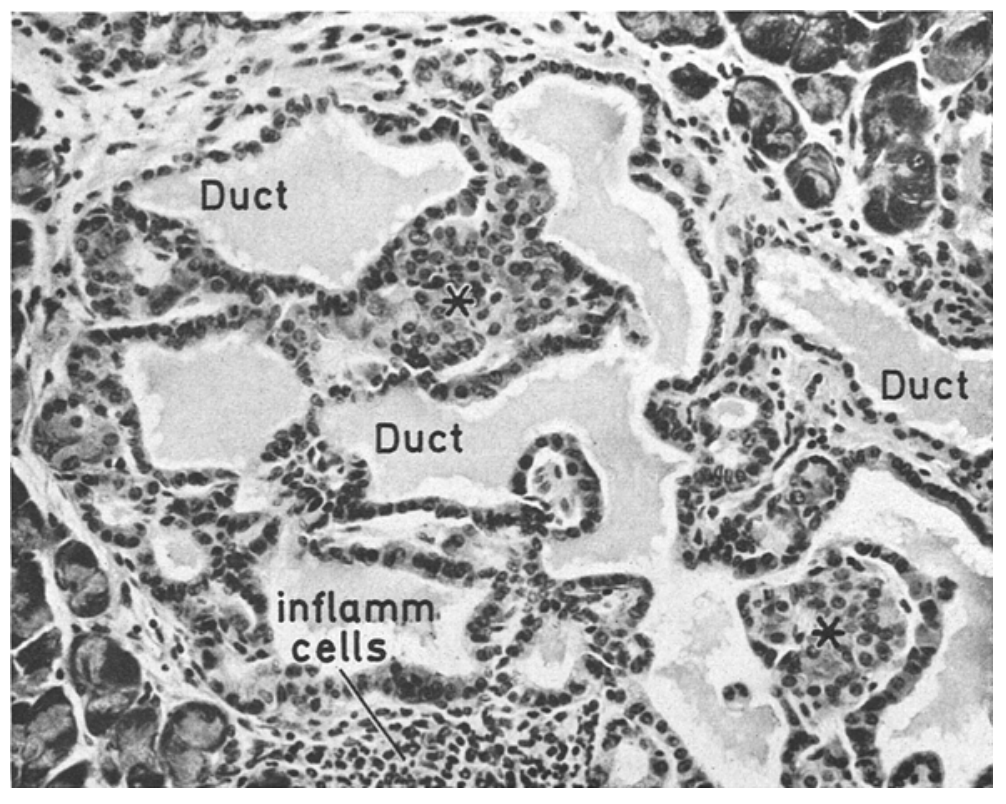

Figs. 9 through 11. Pancreatic islet of diabetic mice in terminal phase of syndrome

Fig. 9. The network of dilated ducts has rendered unrecognizable the islet structure. Small clusters of residual islet cells (*) are present as well as collections of inflammatory cells. Hematoxylin and eosin. $\times 256$. a cell nucleus. They identify the paths of beta particles which originate in newly synthesized tritiated. DNA and pass into and expose the photographic emulsion. For control purposes the presence of heavily labeled crypt cells in the duodenal mucosa was required to verify the successful introduction of thymidine $-{ }^{3} \mathrm{H}$ into the thymidine pool of the mouse. The radioautographic slides were examined and after careful scrutiny the number of labeled cells estimated. In all instances these estimates
The pattern of cell labeling among the islets of animals in the terminal stage of the syndrome is strikingly different. Only an occasional labeled cell is seen among the collections of surviving islet cells. In contrast many of the small ductal structures which surround and permeate the islets contain a large number of labeled cells (Fig. 14). Occasionally, one or more of the small number of intra-islet acinar cells is also labeled. Lastly, a number of labeled inflammatory cells, capillary endo- 
thelial cells and presumptive fibroblasts are also noted. around islets most prominently involved in the inflammatory process (Fig. 14).

The exocrine pancreas of normal mice and mutants are similar in that both reveal only an infrequent labeled acinar cell or ductal cell in portions of the gland at a distance from the islets of Langerhans.

\section{Discussion}

Normal Mice. The light microscopic appearance of the normal $\mathrm{C} 57 \mathrm{BL} / \mathrm{KsJ}$ mice can not be distinguished from that of other inbred or random bred mouse speeies. Factors considered in this evaluation include islet size and shape, the relative positions of the alpha and beta cells, the abundance of aldehyde fuchsin positive
Figs. 10 and 11. Almost all endocrine cells are replaced by small ducts (D) and acinar cells (AC). Inflammation (Figs. 10 and 11) and fibrosis (Fig. 11) are present. The shape of the original islet is retained. Hematoxylin and eosin. $\times 295$

Fig. 10

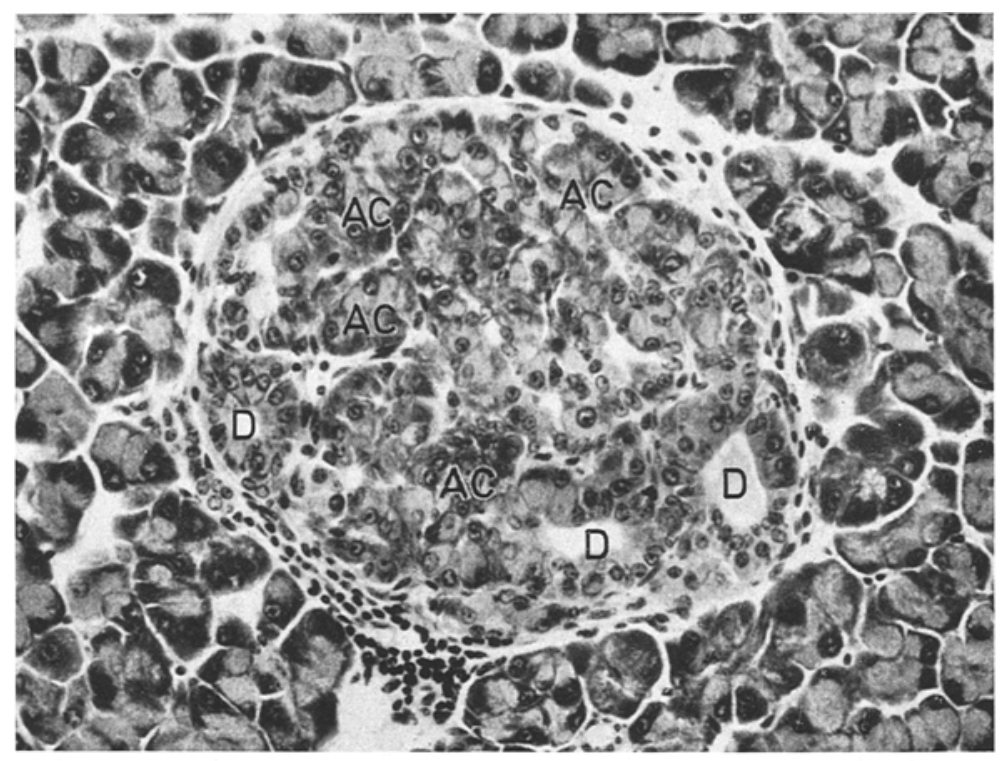

Fig. 11

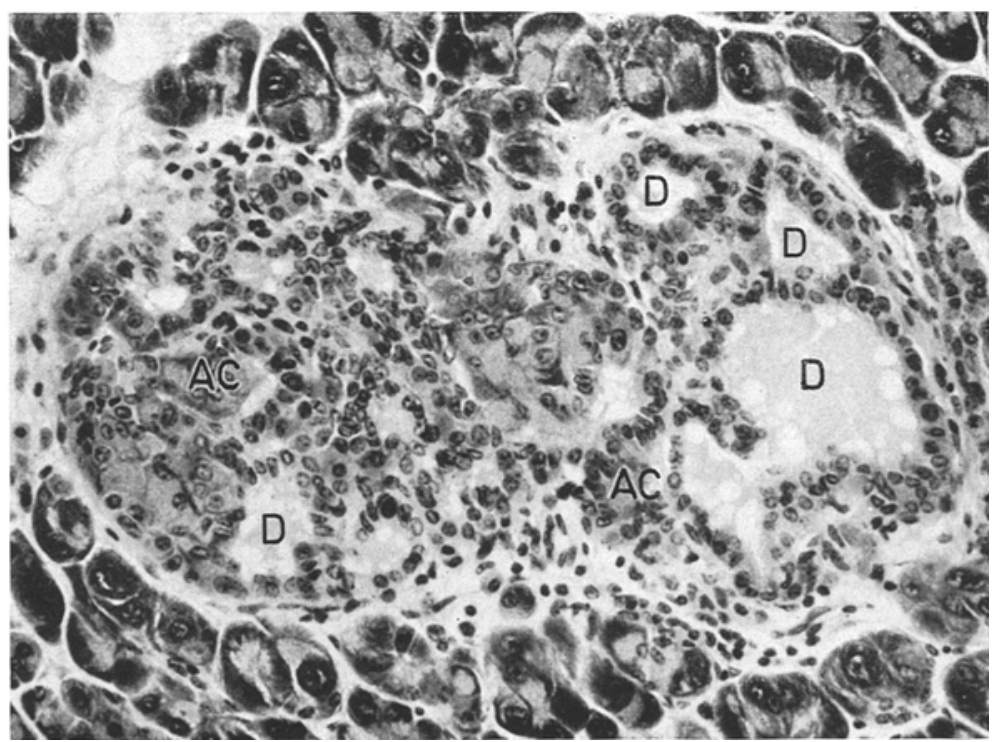

The islets of the two mutants demonstrating early and very severe carbohydrate intolerance were unique in several respects. Although islet size was not increased, beta cell degranulation was complete and only a rare islet cell was labeled with thymidine- ${ }^{3} \mathrm{H}$. Proliferating ducts were not visible. granules within beta cells and the intimate but distinctly separate spatial relationship of islets and exocrine ducts. An additional factor of importance is the very small number of islet cells which incorporate thymidine $-{ }^{3} \mathrm{H}$ after a single intraperitoneal injection, confirming the earlier results of Logothetopoulos [14]. 
Under circumstances of a normal diet, one can predict that in the absence of hyperglycemia, serum IRI levels will be normal, the islets will not be enlarged, beta cells will be well granulated and there will be only minimal evidence of DNA synthesis. sible for the stimulation of beta cell replication. On the other hand, the presence of beta cell degranulation, increased serum IRI and markedly increased islet cell labeling, in association with early hyperglycemia suggests that the blood glucose level may be one of several

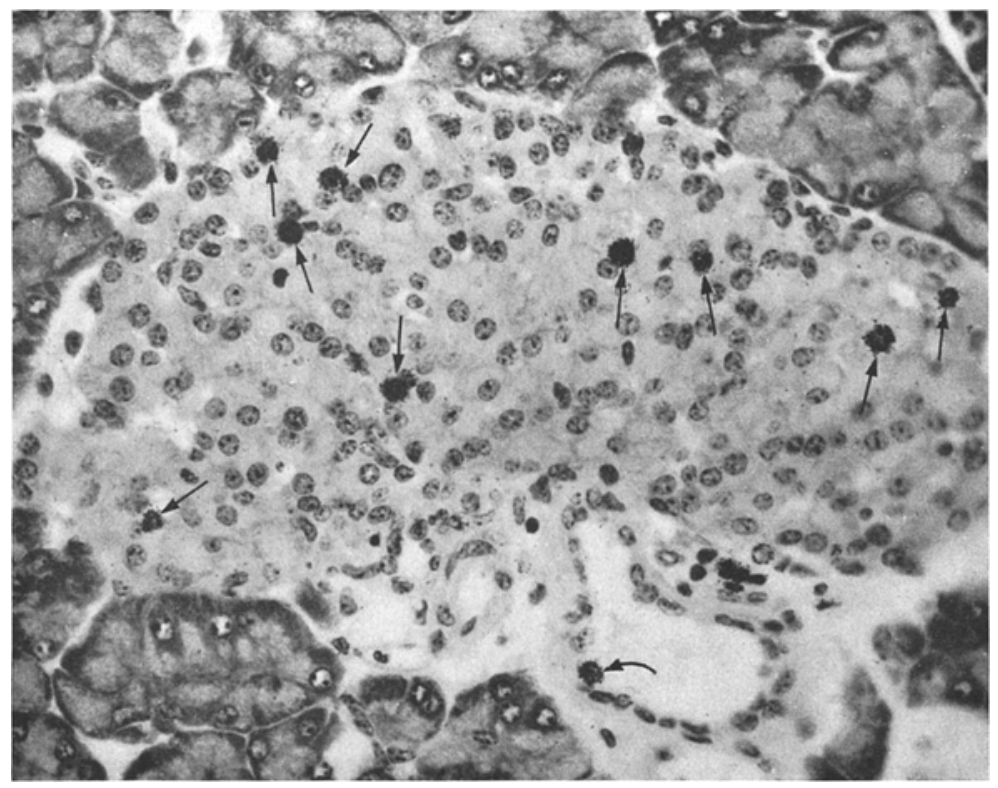

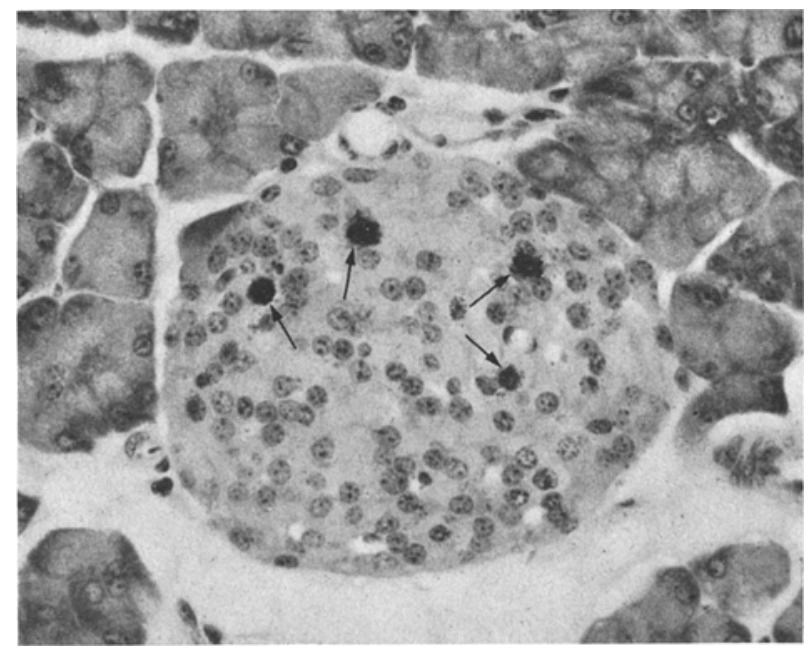

Figs. 12 and 13. Pancreatic islets of a diabetic mouse in early hyperglycemic stage. Radioautographs after thymidine ${ }^{-} \mathrm{H}$ administration. Many islet cells are labeled (arrows) with no preference for large (Fig. 12) or small (Fig. 13) islets. A duct cell is also labeled in Fig. 12 (curved arrow). PAS $\times 500$ (Fig. 12) $\times 400$ (Fig. 13)

Diabetic Mutants. Prior to the onset of hyperglycemia, one can distinguish a majority of mutants from normal mice with the assistance of radioautography. The presence of increased numbers of labeled islet cells in these young prehyperglycemic mutants suggests that factors other than glycemic elevation are respon- stimuli responsible for regulating beta cell proliferation as well as insulin release.

The eventual decrease in the number of beta cells together with a reduction in the frequency of labeled islet cells strongly suggests that in the terminal stage of the syndrome there occurs both a destruction of beta cells as well as a failure of beta cell proliferation. Supporting this concept of beta cell destruction are ultrastructural data [10], the rearrangement of alpha cells into the islet interior and the presence of foci of inflammation and fibrosis. The frequency of labeled ductal cells at a time of decreased islet cell labeling verifies the earlier [2] opinion that duct proliferation occurs and renders unlikely the possibility that the new ducts arise from pre-existing islet (endocrine) cells. The absence of a "second wave" of endocrine islet cells, subsequent to the appearance of proliferating ducts also renders unlikely the possibility that significant numbers of islet cells arise from the newly formed ductal cells. The important question of duct to islet cell transformation and islet cell neogenesis will be discussed in depth in the accompanying publication dealling with the ultrastructural studies [10]. It is obvious, however, from the reduction in islet cell labeling and the eventual reduction in serum IRI that this mutant differs from other species studied $[5,4,16,17,11]$ in that it fails to effect an adequate expansion of its insulin synthesizing capacity, and finally succumbs in a state of relative insulin insufficiency. 
The two mice with early and more profound carbohydrate intolerance offer further support for this viewpoint. In these animals, the limit of insulin production was very quickly reached and the beta cells depleted of stored insulin in the presence of pronounced hyperglycemia. The absence of beta cell labeling in degranulated islets at 8 weeks of age is interpreted as an early manifestation of the genetic inability of this mutant to adequately expand its beta cell mass and hence its insulin synthesizing capacity.
Proc. Internat. Wenner-Gren Symposium, pgs. 4561. Uppsala and Stockholm: Pergamon Press 1964.

7. Hoffman, W.S.: A rapid photoelectric method for determination of glucose in blood and urine. J. biol. Chem. 120, $51-55$ (1937).

8. Hummel, K.P., Dickie, M.M., Coleman, D.L.: Diabetes, a new mutation in the mouse. Science $\mathbf{1 5 3}$, $1127-1128$ (1966).

9. Lacy, P.E., Kostianovsky, M.: Method for the isolation of intact islets of Langerhans from the rat pancreas. Diabetes 16, 35-39 (1967).

10. Like, A.A., Chick, W.L.: Studies in the diabetic
Fig. 14. Pancreatic islet from diabetic mouse in terminal stage. Radioautograph after thymidine ${ }^{3} \mathrm{H}$ administration. Many ductal lining cells are labeled. Residual islet cells (*) are not labeled. Labeled cells between islet and adjacent exocrine tissue include inflammatory cells and fibroblasts. PAS $\times 256$

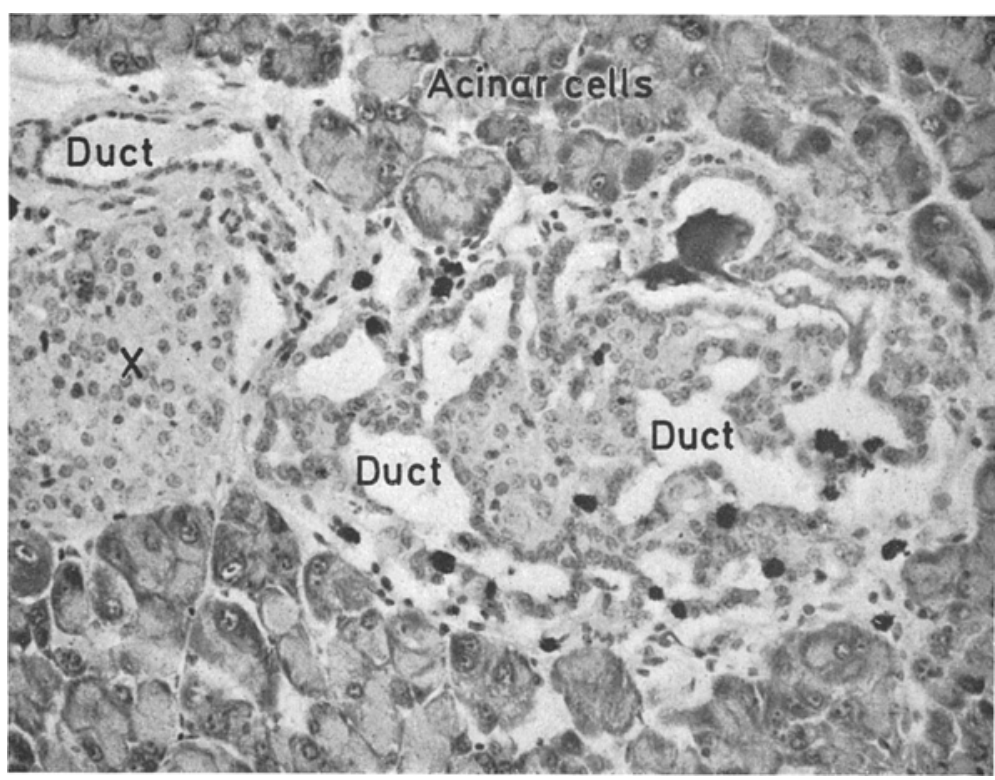

Acknowledgments: The authors wish to acknowledge with appreciation the very generous collaborative assistance and advice provided by Drs. D. L. Coleman and K.P. Hummel (The Jackson Laboratory, Bar Harbor, Maine) during the early period of this investigation, as well as the skillful technical assistance of Miss Pauline Gaudreau, Miss Barbara Beach and Miss Judith Flewelling, and the generous assistance of Dr. S. Ito and Miss J. Mueller, Dept. of Anatomy, Harvard Medical School,

\section{References}

1. Chick, W.L., Like, A.A.: Studies in the diabetic mutant mouse III. Physiological factors associated with alterations in beta cell proliferation. Diabetologia 6. 243-251 (1970)

2. Coleman, D.L., Hummel, K.P.: Studies with the mutation diabetes in the mouse. Diabotologia $\mathbf{3}$, $238-248$ (1967).

3. - - The mutation diabetes in the mouse. Excerpta Med. Proc. 6th Cong. Internat. Diabetes Fed., Stockholm, pp. $813-820$ (1969).

4. Gepts, W., Christophe, J., Mayer, J.: Pancreatic islets in mice with the obese-hyperglycemic syndrome. Lack of effect of carbutamide. Diabetes 9, 63-69 (1960).

5. Gleason, R.E., Lauris, V., Soeldner, J.S.: Studies on experimental diabetes in the Wellesley hybrid mouse III. Dietary effects and similar changes in a commercial Swiss-Hauschka strain. Diabetologia 3, 175-178 (1967).

6. Hellman, B., Petersson, B., Hellerström, C.: The growth pattern of the endocrine pancreas in mammals. mutant mouse Ir. Electron microscopy of pancreatic islets. Diabetologia 6, 216-242 (1970).

11. - Miki, E.: Diabetic syndrome in sand rats IV. Morphologic changes in islet tissue. Diabetologia $3,143-166(1967)$.

12. - Jones, E.F.: Studies on experimental diabetes in the Wellesley hybrid nouse IV. Morphologic changes in islet tissue. Diabetologia 3, 179-187 (1967).

13. - Steinke, J., Jones, E.E., Cahill, G.F., Jr.: Pancreatic studies in mice with spontaneous diabetes mellitus. Amer. J. Path. 46, 621 - 644 (1965).

14. Logothetopoulos, J., Bell, E.G.: Histological and autoradiographic studies of the islets of mice injected with insulin antibody. Diabetes 15, 205-211 (1966).

15. Morgan, C.R., Lazarow, A.: Immunoassay of insulin: two antibody system. Diabetes 12, 115-126 (1963).

16. Nakamura, M.: Cytological and histological studies on the pancreatic islets of a diabetic strain of the mouse. Z. Zellforsch. 65, 340-349 (1965).

17. - Yamada, K.: Studies on a diabetic (KK) strain of the mouse. Diabetologia 3, 212-221 (1967).

18. Soeldner, J.S., Slone, D.: Critical variables in the radioimmunoassay of serum insulin using the double antibody technique. Diabetes 14, 771-779 (1965).

19. Warren, S., LeCompte, P.: The pathology of diabetes mellitus, 3rd ed., p. 325. Philadelphia: Lea and Febiger 1952 .

Arthur A. Like, M.D.

Elliott P. Joslin Research Laboratory

170 Pilgrim Road

Boston, Massachusetts 02215, USA 